JACEK SOtTYS

Politechnika Gdańska, Polska - Gdansk University of Technology, Poland

SŁAWOMIR DOROCKI

Uniwersytet Pedagogiczny w Krakowie, Polska - Pedagogical University of Cracow, Poland

\title{
Wskaźnik przedsiębiorczości w jednostkach terytorialnych Polski - zróżnicowanie w czasie i przestrzeni
}

\author{
Indicator of Entrepreneurship in the Polish Territorial Units - Diversity in Time and Space
}

Streszczenie: Przedmiotem artykułu jest analiza zjawiska prowadzenia działalności gospodarczej przez osoby fizyczne, mierzonego wskaźnikiem liczby tych osób na 100 osób w wieku produkcyjnym. Wskaźnik ten nazywany jest nieraz wskaźnikiem przedsiębiorczości, mimo że mierzy tylko jeden z jej przejawów. Badania prowadzono w układzie podregionów, powiatów i gmin (według ich rodzaju, $\mathrm{z}$ wyodrębnieniem miast w gminach miejsko-wiejskich). Celem badań było poznanie zróżnicowania badanego wskaźnika w czasie, przestrzeni, w zależności od rodzaju jednostki terytorialnej i wielkości miasta (w przypadku miast) oraz uzyskanie odpowiedzi na pytania: Czy można zauważyć i wyjaśnić prawidłowości? Czy można stwierdzić stan nasycenia w niektórych jednostkach? Jako metody stosowano: analizy statystyczne rozkładów wskaźników stanu i dynamiki, wykresy, analizy kartograficzne oraz badanie korelacji wskaźników stanu i dynamiki ze sobą oraz z liczbą ludności miast, bezrobociem, PKB (dla podregionów) i dochodami własnymi gmin. Stwierdzono duże zróżnicowanie wskaźników i następujące prawidłowości: wskaźniki stanu w miastach są wyższe niż na wsi, nie ma korelacji z wielkością miast, najwyższe wskaźniki występują na obszarach turystycznych i metropolitalnych, a najniższe - we wschodniej Polsce. Niewiele jest prawidłowości w dynamice zjawiska. Przedsiębiorczość przejawiająca się w tworzeniu firm w większym stopniu niż czynnikiem rozwoju jest efektem rozwoju wywołanym przez inne czynniki.

\begin{abstract}
The subject of the article is to analyze the phenomenon of economic activity by natural persons, measured by an indicator of the number of these persons to 100 persons at working age. This indicator is sometimes called the indicator of entrepreneurship, although it only measures one of its aspects. The study was conducted on the level of sub-regions, poviats (counties) and gminas (municipalities - according to their kinds, including towns in urban-rural gminas). The objective of the study was to recognize the diversity in the examined indicator in time and space, depending on the kind of a territorial unit and the size of the town (in case of towns) as well as to obtain the answers to the following questions: Can any regularity be noticed and explained? Can the state of saturation be verified in some units? The methods of research included: statistical analysis of indicators of states and dynamics, charts, cartographic analysis, and examining the correlation of indicators of states and dynamics with each other and with the towns' population, unemployment, GDP (subregions) and the revenue of municipalities. A large diversity of indicators and the following regularity were found: indicators in towns are generally higher than in rural areas, there is no correlation with the size of towns; the highest indicators are in metropolitan and tourist areas, the lowest - in the East of Poland. There are little regularities in the dynamics of the phenomenon. Entrepreneurship as a creation of companies rather than a factor of development is the result of development caused by other factors.
\end{abstract}


Słowa kluczowe: działalność gospodarcza; gmina; podmioty osób fizycznych; podregion; Polska; powiat; przedsiębiorczość - wskaźnik

Key words: county; economic activity; entities of natural persons; entrepreneurship - indicator; municipality; Poland; sub-region

Otrzymano: 22 listopada 2015

Received: 22 November 2015

Zaakceptowano: 6 marca 2016

Accepted: 6 March 2016

\section{Sugerowana cytacja/Suggested citation:}

Sołtys, J., Dorocki, S. (2016). Wskaźnik przedsiębiorczości w jednostkach terytorialnych Polski zróżnicowanie w czasie i przestrzeni. Przedsiębiorczość - Edukacja, 12, 18-35.

\section{Wstęp}

Przedmiotem artykułu jest analiza zjawiska prowadzenia działalności gospodarczej przez osoby fizyczne mierzonego przez wskaźnik liczby tych osób na 100 osób w wieku produkcyjnym. Wskaźnik ten zwany będzie krócej liczbą przedsiębiorców na 1000 ludności w wieku produkcyjnym, a najkrócej - wskaźnikiem badanym lub wskaźnikiem stanu w odróżnieniu od wskaźnika dynamiki. Nazywanie wymienionego wskaźnika wskaźnikiem przedsiębiorczości jest uproszczeniem, nie tylko dlatego, że trudno nazwać przedsiębiorczością samozatrudnienie wymuszane przez niektórych pracodawców, ale również dlatego, że przedsiębiorczość jest pojęciem złożonym, wieloaspektowym, a zakładanie i prowadzenie przedsiębiorstw jest tylko jednym z jej przejawów (Kudłacz, Reśko, 2007; Dorocki, Brzegowy, 2014; Płaziak, Rachwał, 2015). Często jednak w literaturze przyjmuje się taką nazwę badanego wskaźnika lub jego odmian, np. uwzględniających ogół podmiotów gospodarczych (Iwańska, Bieńkowska, 2010; Salamon, 2009) lub wszystkich podmiotów gospodarki narodowej według GUS (co nie jest właściwe, ponieważ obejmują one m.in. instytucje publiczne, wspólnoty mieszkaniowe, organizacje i stowarzyszenia), odnoszonych czasem do ogółu ludności.

W Polsce dynamiczny wzrost liczby osób fizycznych prowadzących działalność gospodarczą nastąpił po przemianie ustrojowej, ale proces zaczął się po przyjęciu ustaw gospodarczych rządu Rakowskiego na przełomie 1988 i 1989 r. Liczba badanych firm w skali kraju wciąż wykazuje tendencję rosnącą. Jednym z motywów podjęcia badań jest duża rola, jaką strategie, polityki i programy rozwoju odgrywają w tworzeniu nowych firm. Można zadać pytanie, czy rola ta nie jest nadmierna, zważywszy, że: 1) większość osób prowadzi działalność jednoosobowo (nie są to więc firmy mogące być motorami rozwoju, działają one głównie w sektorze endogenicznym); 2) tworzeniu nowych firm towarzyszy likwidacja firm istniejących: w $2011 \mathrm{r}$. tylko 77\% firm przeżywało rok, 54\% - 2 lata, 32\% - 5 lat (Raport..., 2013); 3) Polska znajduje się już w czołówce europejskiej pod względem zakładania i zamiarów założenia firmy (Raport..., 2013); 4) udział osób przedsiębiorczych w populacji jest ograniczony. Pojawia się zatem pytanie o to, w jakiej skali przyrosty liczby firm są jeszcze możliwe i czy w niektórych jednostkach nie został już osiągnięty stan nasycenia.

Prowadzenie działalności gospodarczej przez osoby fizyczne było przedmiotem wielu badań. Dotyczyły one przeważnie jednostek terytorialnych jednego poziomu, np. województw w skali kraju lub jego części (np. Kurek, 2010; Rachwał, Boguś, 2012; Strojny, Kościółek, 2015), powiatów lub gmin w jednym województwie lub jego części (np. Kudłacz, Reśko, 2007; 
Krakowiak-Bal, 2007; Salamon, 2009; Iwańska, Bieńkowska, 2010; Strojny, 2010; Dorocki, Brzegowy, 2012). W odróżnieniu od powyższych publikacji w badaniach prezentowanych w niniejszym artykule zjawisko - jego stan i dynamika - analizowane było dla całej Polski na trzech poziomach: podregionów NTS3, powiatów i gmin z wyodrębnieniem miast z gmin miejsko wiejskich w celu badania całego ich zbioru. Celem prezentowanych badań było poszukiwanie odpowiedzi na pytania:

1. Jakie jest zróżnicowanie badanego wskaźnika w czasie i przestrzeni?

2. Czy ma miejsce i jakie jest zróżnicowanie badanego wskaźnika w zależności od rodzaju jednostki terytorialnej i wielkości miasta (w przypadku miast)?

3. Czy można zauważyć i wyjaśnić prawidłowości?

4. Czy można stwierdzić stan nasycenia w niektórych jednostkach?

Celem badań nie było natomiast wyjaśnienie przyczyn zróżnicowania badanego zjawiska. Wymaga ono obszerniejszych badań opartych na szerokim materiale źródłowym.

Źródłem informacji był Bank Danych Lokalnych GUS (Bank) opierający się na REGON-ie, mimo iż zgłaszano zastrzeżenia co do prawdziwości zawartych tam danych (Kudłacz, Reśko, 2007) wobec braku mechanizmu wymuszającego wyrejestrowanie podmiotu po zaprzestaniu działalności. Wprowadzenie tzw. jednego okienka i weryfikacja przeprowadzona przez GUS w 2011 r. uwiarygodniają informacje dla tegoż roku i lat następnych. Lata objete badaniem (2002-2014) wynikają z dostępności danych w powyższym źródle. Dla gmin są to lata 2009-2014, ponieważ tylko w nich badane wielkości dla gmin miejsko-wiejskich podawane są $\mathrm{z}$ rozróżnieniem miast i wsi.

Jako metody stosowano: analizy statystyczne rozkładów wskaźników stanu i dynamiki, wykresy, analizy kartograficzne oraz badanie korelacji (wskaźników stanu i dynamiki ze sobą oraz z liczbą ludności miast, bezrobociem, PKB w badaniu podregionów i z dochodami własnymi gmin w badaniu gmin) z użyciem współczynnika Pearsona. Wprowadzono grupowanie położenia jednostek, rozróżniając następujące typy obszarów: 1) metropolitalne; 2) niemetropolitalne miasta wojewódzkie wraz z otoczeniem (powiat, a dla Rzeszowa podregion NTS3); 3) inne obszary tzw. pośrednie między metropolitalnymi a peryferyjnymi, w tym górniczo-przemysłowe (podregiony NTS3: bielski, częstochowski, legnicki i rybnicki); 4) peryferyjne poza powyższymi. Za obszary metropolitalne uznano te wskazane w Koncepcji przestrzennego zagospodarowania kraju 2030 (Koncepcja..., 2011), a ich granice przyjęto według Unii Metropolii Polskich (Młodak, 2012), nie tylko z powodu operowania pełnymi podregionami, ale i ze względu na lepsze dostosowanie takiego układu do rozkładu badanego zjawiska i wyjaśnianie go. Wyróżniono też obszar tzw. Polski Wschodniej za Programem Rozwoju Polski Wschodniej (Rozwój..., 2015) oraz powiaty turystyczne (opisane w odpowiednim rozdziale).

\section{Przedsiębiorcy w skali kraju i w podregionach}

W Polsce w 2002 r. było ok. 2,7 mln osób fizycznych prowadzących działalność gospodarczą, a w 2014 r. - prawie 3 mln. Stanowiło to w tych latach odpowiednio 93\% i 87\% ogółu podmiotów gospodarczych. Szacuje się, że ponad 1,5 mln, a więc większość osób fizycznych, prowadzi działalność jednoosobowo.

Przyrost lub ubytek liczby podmiotów stanowi tylko niewielką część liczby podmiotów nowo zarejestrowanych i wyrejestrowanych (ryc. 1). Liczba tych pierwszych w całym kraju rosła z roku na rok w latach 2004-2010, a po spadku w 2011 r. jest dość stabilna. Liczba podmiotów wyrejestrowanych wykazuje większą zmienność. Skokowe wzrosty w porównaniu 
z poprzednim rokiem mały miejsce w latach: 2009 (co można wiązać z kryzysem) i 2011 (weryfikacja REGON-u). Przyczyniły się one do spadków liczby podmiotów (największy spadek to wynik weryfikacji w 2011 r.). Do zmian tych, poza globalnymi i regionalnymi zmianami koniunktury gospodarczej, mogły przyczynić się: zmiany przepisów, wymuszanie przez pracodawców samozatrudnienia (i jego ograniczanie bądź zaniechanie) oraz polityka wsparcia, np. okresowe ulgi dla nowych firm i dotacje dla bezrobotnych podejmujących działalność gospodarczą. Wprowadzenie takich instrumentów zwiększa liczbę powstających podmiotów, a koniec ich funkcjonowania skutkuje likwidacją wielu $\mathrm{z}$ nich.

Ryc. 1. Nowo zarejestrowane i wyrejestrowane osoby fizyczne prowadzące działalność gospodarczą w Polsce w latach 2003-2014

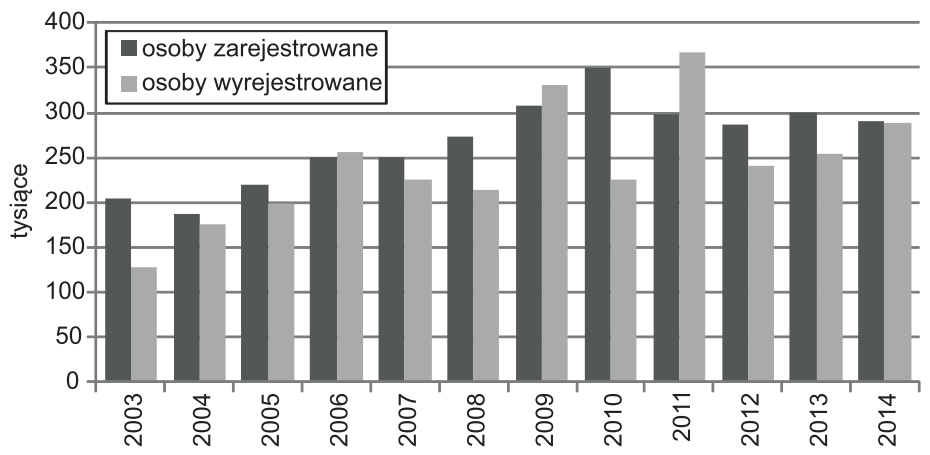

Źródło: opracowanie własne na podstawie danych z Banku Danych Lokalnych GUS

Przyrosty liczby osób prowadzących działalność różnią się zależnie od sposobu liczenia, ale różnice nie są duże (ryc. 2). Największa rozbieżność była w roku 2004. Na różnice mógł wpłynąć przepis likwidujący rejestrację w gminach spółek cywilnych i wymuszający odrębną rejestrację każdego wspólnika jako osobę fizyczną. Pozostały natomiast spółki cywilne w REGON.

Ryc. 2. Przyrosty liczby osób fizycznych prowadzących działalność gospodarczą w Polsce w latach 2003-2014 liczone różnymi sposobami

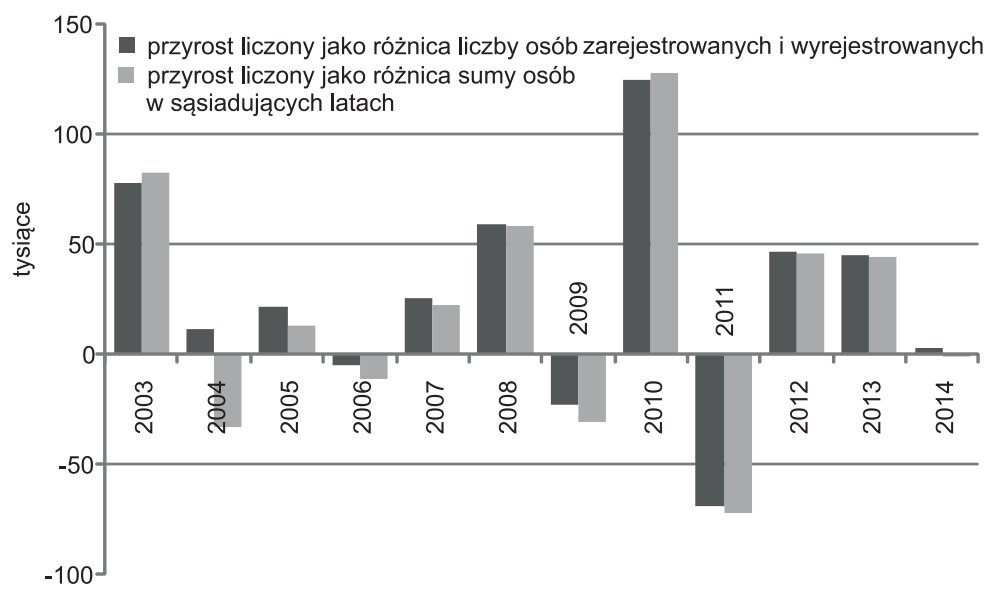

Źródło: opracowanie własne na podstawie danych z Banku Danych Lokalnych GUS 
Liczba przedsiębiorców na 100 osób w wieku produkcyjnym w całym badanym okresie najwyższa była $\mathrm{w}$ podregionach miejskich, innych metropolitalnych i nadmorskich, najniższa - w podregionach peryferyjnych Polski Wschodniej (ryc. 3 i 4, tab. 1). Na 13 podregionów o najwyższych wskaźnikach były 2 niemetropolitalne w 2002 r. (na 2 miejscu koszaliński i na 10 - bielski), w 2014 r. - tylko 1 (koszaliński, na 8 miejscu). Na najniższym, 44 miejscu wśród podregionów metropolitalnych w 2014 r. był podregion bytomski. Wśród 12 podregionów o najniższych wskaźnikach (9 i mniej) większość stanowiły podregiony peryferyjne z Polski Wschodniej: 7 w 2002 r. i 10 w 2014 r. Najwyższe miejsca podregionów z Polski Wschodniej w 2014 r. to: 24 - podregion kielecki, a z podregionów peryferyjnych: 66 - podregion krośnieński. Wielkości syntetycznie charakteryzujące grupy podregionów zawiera tabela 1.

Ryc. 3. Liczba osób fizycznych prowadzących działalność gospodarczą na 100 osób w wieku produkcyjnym wg podregionów NTS3 w 2002, 2009 i 2014 r.
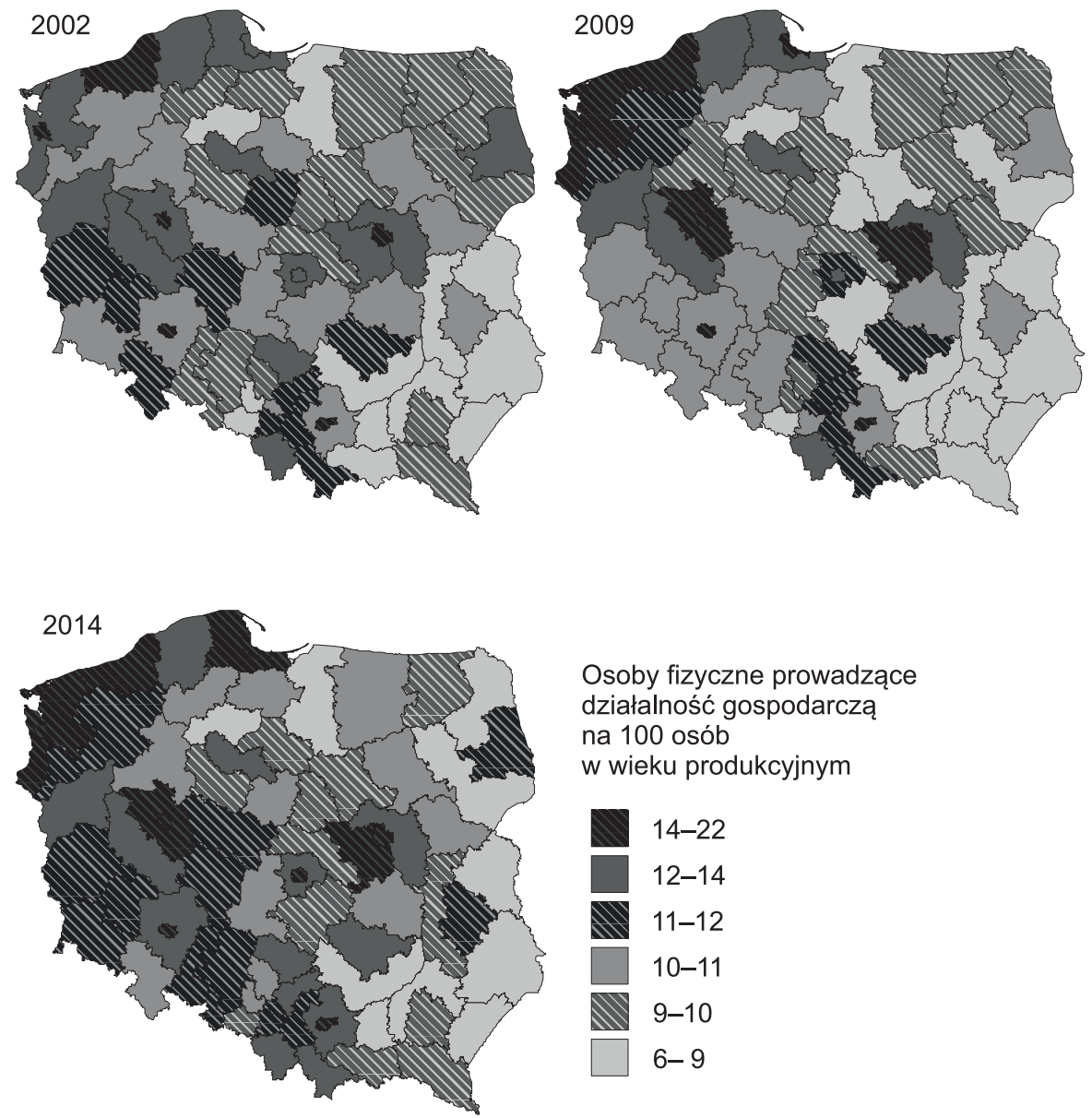

Osoby fizyczne prowadzące działalność gospodarczą na 100 osób w wieku produkcyjnym

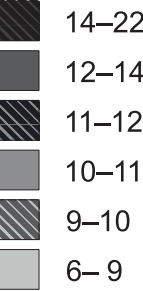


Tab. 1. Liczba osób fizycznych prowadzących działalność gospodarczą na 100 osób w wieku produkcyjnym - stany i dynamika w latach 2002-2014 według typów podregionów

\begin{tabular}{|l|c|c|c|c|c|c|}
\hline \multicolumn{1}{|c|}{$\begin{array}{c}\text { Podregiony } \\
\text { (wg typu) }\end{array}$} & Min. & Maks. & Średnia & $\begin{array}{c}\text { Odchylenie } \\
\text { standardowe } \\
\text { średnie }\end{array}$ & $\begin{array}{c}\text { Dynamika } \\
\text { 2002-2014 }\end{array}$ & $\begin{array}{c}\text { Udział podregionów } \\
\text { ze spadkami } \\
\text { wskaźnika }\end{array}$ \\
\hline metropolitalne & 8,7 & 20,8 & 13,4 & 2,7 & 96,2 & 20,0 \\
\hline $\begin{array}{l}\text { miast } \\
\text { wojewódzkich }\end{array}$ & 7,5 & 12,3 & 10,4 & 0,9 & 111,1 & 33,3 \\
\hline $\begin{array}{l}\text { inne w „obszarach } \\
\text { pośrednich” }\end{array}$ & 6,9 & 12,7 & 10,8 & 1,5 & 103,8 & 20,0 \\
\hline $\begin{array}{l}\text { peryferyjne Polski } \\
\text { Wschodniej }\end{array}$ & 7,2 & 13,8 & 10,8 & 1,6 & 102,2 & 45,5 \\
\hline $\begin{array}{l}\text { peryferyjne } \\
\text { pozostałe }\end{array}$ & 7,3 & 17,2 & 9,7 & 1,7 & 97,9 & 48,1 \\
\hline
\end{tabular}

Źródło: opracowanie własne na podstawie danych pochodzących z Banku Danych Lokalnych GUS

Ryc. 4. Liczba osób fizycznych prowadzących działalność gospodarczą na 100 osób w wieku produkcyjnym - średnie arytmetyczne dla grup podregionów NTS3

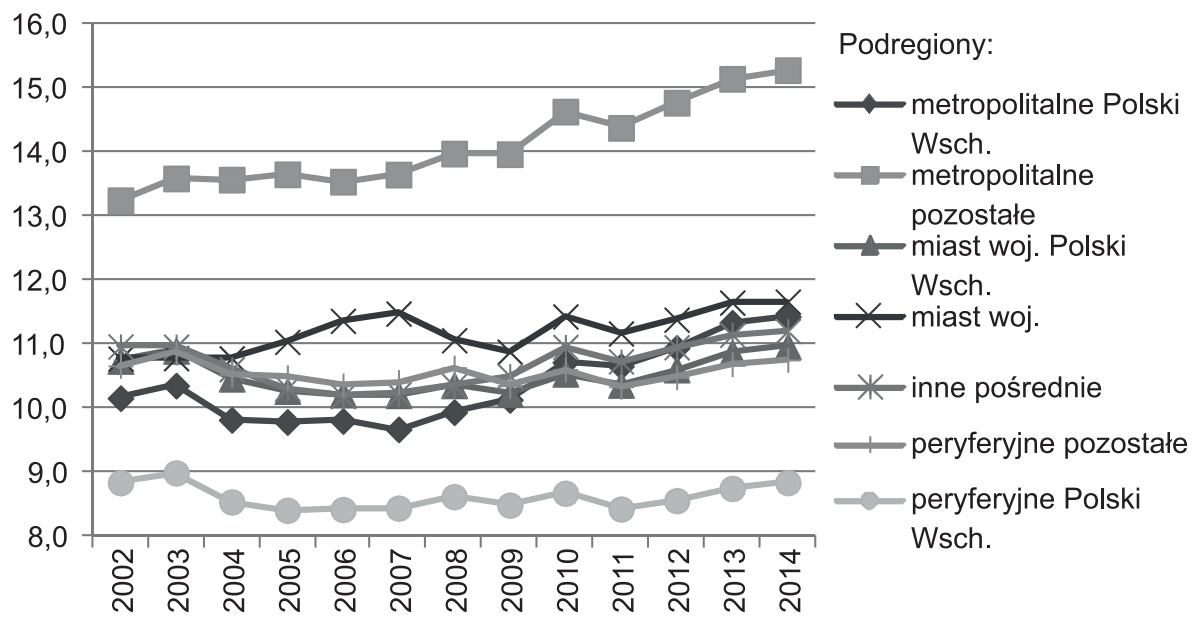

Źródło: opracowanie własne na podstawie danych z Banku Danych Lokalnych GUS

W analizie dynamiki rozróżnia się zmiany liczby podmiotów i zmiany wskaźnika, które różnią się z powodu zmian liczby ludności w wieku produkcyjnym. Wśród podregionów o najwyższej dynamice wskaźnika w latach 2002-2014 również dominują podregiony metropolitalne. Na 12 podregionów o dynamice powyżej 115 są tylko 2 podregiony niemetropolitalne: na 3 miejscu znajduje się podregion nowosądecki (dynamika 123,8) i na 8 miejscu podregion opolski $(118,5)$. W 17 podregionach w latach 2002-2014 spadła liczba podmiotów, natomiast wskaźnik na 100 osób w wieku produkcyjnym zmniejszył się aż w 23 podregionach: 2 metropolitalnych (bydgosko-toruńskim i łódzkim), 2 - miast wojewódzkich (białostockim i zielonogórskim), w legnicko-głogowskim i 18 podregionach peryferyjnych, w tym 4 z Polski 
Wschodniej. Dynamikę wskaźnika poniżej 95\% miało 8 podregionów peryferyjnych, w tym 2 Polski Wschodniej (łomżyński i suwalski).

Zarówno wzrosty, jak i spadki nie trwają nieprzerwanie. Wiele podregionów miało zróżnicowane przebiegi zmienności (ryc. 5 i 6). Prawdopodobne jest, że do niektórych przynajmniej spadków między rokiem 2008 a 2009 przyczyniły się kryzys globalny i krajowe spowolnienie. Spadki liczby podmiotów w tym okresie wystąpiły w 39 podregionach, w 12 z nich przekroczyły 5\% stanu z 2008 r. W roku 2008 ujemna różnica dotyczyła tylko 19 podregionów, w 7 były to spadki powyżej 5\%. Największe spadki dotknęły podregiony Łódzkiego Obszaru Metropolitalnego. We wszystkich podregionach wskaźnik w roku 2014 był wyższy niż w 2011. Niemal we wszystkich podregionach o dynamice w latach 2002-2014 poniżej 100 wskaźnik rósł stale w latach 2011-2014.

Ryc. 5. Liczba osób fizycznych prowadzących działalność gospodarczą na 100 osób w wieku produkcyjnym - dynamika zmian liczby podmiotów
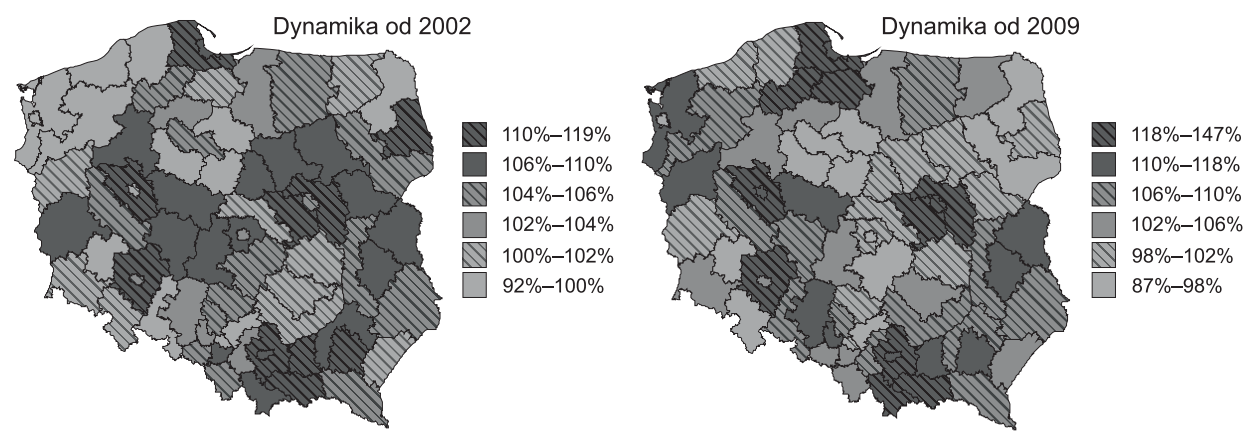

Źródło: opracowanie własne na podstawie danych pochodzących z Banku Danych Lokalnych GUS

Ryc. 6. Liczba osób fizycznych prowadzących działalność gospodarczą na 100 osób w wieku produkcyjnym - podregiony o najniższej dynamice

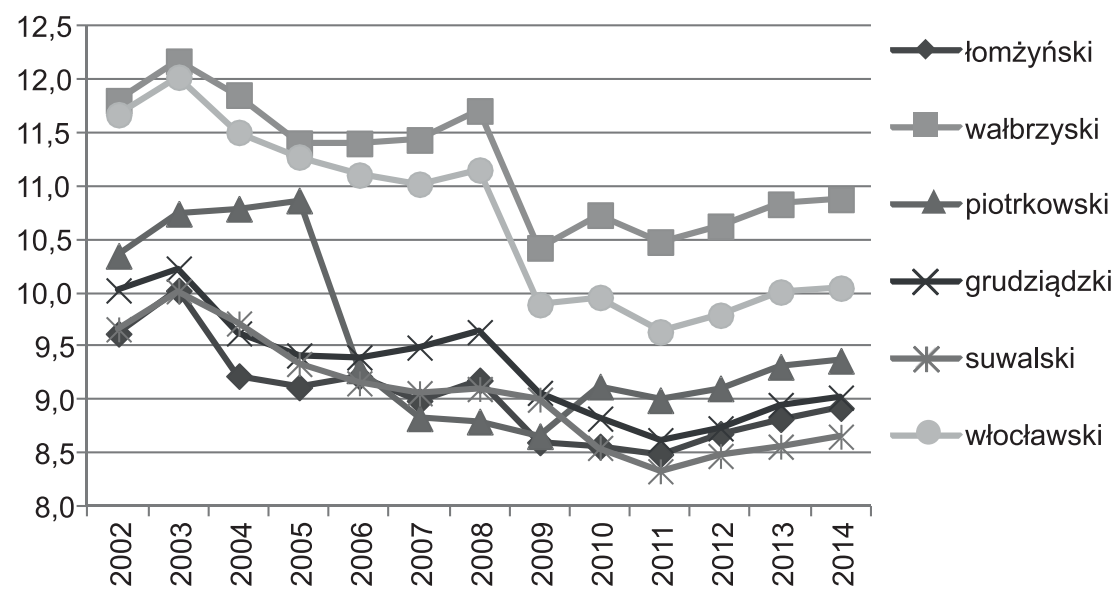

Źródło: opracowanie własne na podstawie danych pochodzących z Banku Danych Lokalnych GUS 
Korelacja dynamiki w latach 2002-2014 ze wskaźnikami stanu w roku 2002 jest słaba (współczynnik korelacji Pearsona 0,211), a jeszcze niższa - dynamiki w latach 2009-2014 ze stanami w roku 2009 (0,108). Badania w układzie podregionów równolegle do badań w układzie powiatów i gmin uzasadnione są m.in. możliwością analizy korelacji liczby badanych firm z PKB. Była ona bardzo wysoka (współczynnik korelacji Pearsona 0,934-0,950 w latach 2002-2012). Badane podmioty współtworzą rozwój, ale inne firmy mają na niego przeważnie większy wpływ. Tak wysoka korelacja świadczy o tym, że liczba badanych firm w znacznie większym stopniu jest skutkiem rozwoju wywołanym przez inne czynniki niż czynnikiem rozwoju.

\section{Przedsiębiorcy w powiatach}

Prawidłowości w układzie powiatów są podobne jak w układzie podregionów: najwyższe wskaźniki w obszarach metropolitalnych i nadmorskich, malejące w kierunku z zachodu na wschód, generalnie wyższe w roku 2002 niż w 2014 (ryc. 7). Widoczne są wyższe wskaźniki w powiatach turystycznych, dość wysokie na pojezierzach, zróżnicowane w powiatach górskich, wyraźnie wyższe w 2014 r. w Karpatach na wschód od linii Kraków-Zakopane. Niektóre wielkości charakteryzujące grupy powiatów według ich typów przedstawiono w tabeli 2, a ich wielkości średnie w kolejnych latach - na rycinie 8.

Ryc. 7. Liczba osób fizycznych prowadzących działalność gospodarczą na 100 osób w wieku produkcyjnym w latach 2002-1014 według powiatów w roku 2002 i 2014
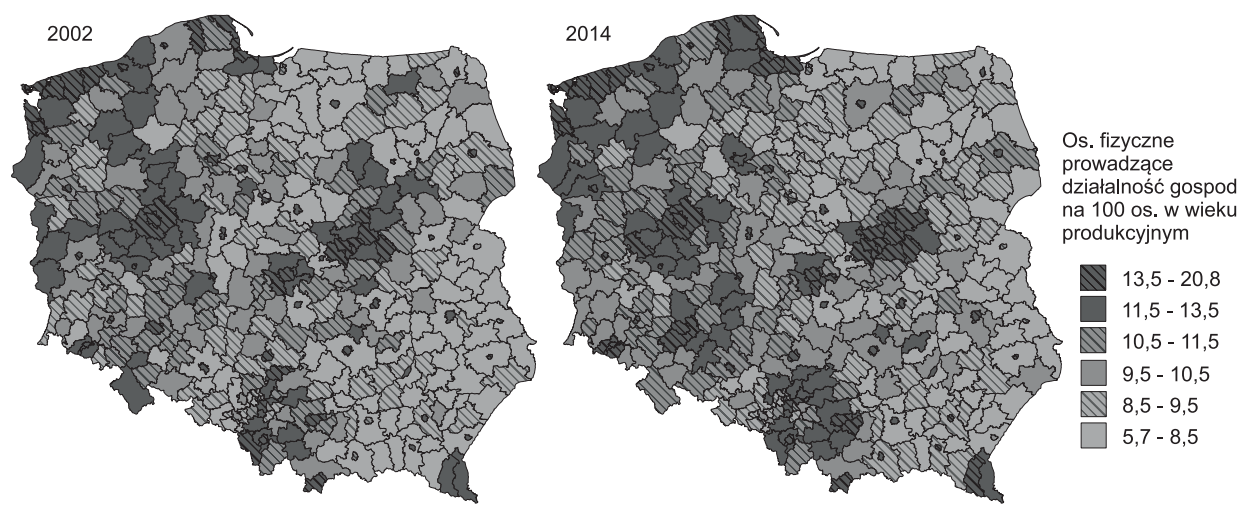

Źródło: opracowanie własne na podstawie danych z Banku Danych Lokalnych GUS

Najbardziej zróżnicowane grupy stanowią powiaty grodzkie metropolitalne i ziemskie turystyczne (10 nadmorskich, 17 górskich i 13 pojeziernych, do których zaliczono powiaty z większymi jeziorami: drawski, szczecinecki, bytowski, chojnicki, człuchowski, kościerski, iławski, ostródzki, ełcki, giżycki, piski, węgorzewski, mrągowski). Najbardziej jednorodna jest grupa 11 powiatów z otoczenia miast wojewódzkich, ale i tu wskaźniki maksymalne są dwukrotnie wyższe od wskaźników minimalnych. Podobną grupę stanowi 11 powiatów ziemskich na pozostałych obszarach uznanych za pośrednie między metropolitalnymi a peryferyjnymi. Ich wskaźniki o skrajnych wartościach są nieznacznie wyższe i w 3 powiatach spadły. W powiatach $\mathrm{z}$ otoczenia miast wojewódzkich spadek był tylko $\mathrm{w}$ powiecie łańcuckim, a cała ta 
grupa odnotowała dynamikę zbliżoną do najwyższych - powiatów metropolitalnych grodzkich i ziemskich. Podobne do siebie są też grupy powiatów grodzkich miast wojewódzkich i innych obszarów pośrednich. Względnie jednorodne są największe grupy powiatów, mimo ich liczebności: 66 powiatów peryferyjnych Polski Wschodniej i 129 pozostałych powiatów peryferyjnych, choć i tu wskaźniki maksymalne są prawie trzykrotnie wyższe od minimalnych. Wartości skrajne oraz średnia stawiają grupę powiatów peryferyjnych Polski Wschodniej na ostatnim miejscu pod względem badanego wskaźnika.

Tab. 2. Liczba osób fizycznych prowadzących działalność gospodarczą na 100 osób w wieku produkcyjnym w latach 2002-1014 - stany i dynamika według typów powiatów

\begin{tabular}{|c|c|c|c|c|c|c|c|}
\hline \multirow{2}{*}{\multicolumn{2}{|c|}{ Powiaty (wg typu) }} & \multicolumn{4}{|c|}{ W całym okresie 2002-2014 } & \multicolumn{2}{|c|}{ Dynamika } \\
\hline & & $\min$. & maks. & średnia & $\begin{array}{c}\text { odchylenie } \\
\text { standardowe } \\
\text { średnie }\end{array}$ & $\begin{array}{c}2002-2014 \\
(2002=100)\end{array}$ & $\begin{array}{l}\text { od min. } \\
\text { do maks. }\end{array}$ \\
\hline \multirow{4}{*}{ 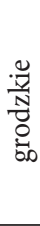 } & metropolitalne & 6,8 & 20,8 & 15,0 & 3,33 & 116,4 & 116,4 \\
\hline & miast woj. & 11,8 & 17,6 & 14,2 & 1,48 & 103,0 & 108,2 \\
\hline & $\begin{array}{l}\text { inne w obszarach } \\
\text { pośrednich }\end{array}$ & 7,3 & 16,9 & 12,4 & 2,78 & 103,0 & 110,8 \\
\hline & peryferyjne & 9,2 & 20,5 & 13,0 & 2,28 & 98,1 & 107,1 \\
\hline \multirow{6}{*}{ 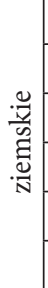 } & metropolitalne & 5,5 & 20,1 & 12,1 & 2,47 & 115,5 & 115,5 \\
\hline & miast woj. & 6,2 & 12,9 & 8,8 & 1,40 & 114,5 & 118,2 \\
\hline & inne pośrednie & 7,5 & 14,3 & 9,8 & 1,68 & 103,5 & 110,8 \\
\hline & turystyczne & 6,6 & 22,2 & 11,1 & 3,41 & 102,5 & 105,6 \\
\hline & peryferyjne wschodnie & 4,4 & 13,1 & 8,2 & 1,47 & 102,1 & 106,7 \\
\hline & peryferyine pozostałe & 4,9 & 14,6 & 10,0 & 1,60 & 101,1 & 106,1 \\
\hline
\end{tabular}

Źródło: opracowanie własne na podstawie danych z Banku Danych Lokalnych GUS

Wśród powiatów ziemskich o wskaźniku powyżej 15 w 2002 r. były 4 powiaty na obszarach metropolitalnych i 6 powiatów na obszarach turystycznych (z wyjątkiem powiatu tatrzańskiego) - nadmorskich (powiat pucki tu liczono w obu tych obszarach). W 2014 r. wskaźnik 15 przekroczyło jeszcze 6 powiatów na obszarach metropolitalnych i 1 na obszarach turystycznych. W kolejnych 15 powiatach (wskaźnik powyżej 13,2) tylko 2 powiaty (wolsztyński i wrzesiński) są poza obszarami metropolitalnymi i turystycznymi. W 152 powiatach ziemskich badany wskaźnik w 2014 r. wynosił 10 lub więcej.

W 2002 r. badany wskaźnik nie osiągnął wartości 7,5 w 40 powiatach ziemskich, wśród których 70\% stanowiły powiaty Polski Wschodniej. W 2014 r. tylko 21 powiatów miało wskaźnik poniżej 7,5, ale były wśród nich tylko 2 powiaty spoza Polski Wschodniej: zwoleński z województwa łódzkiego i dąbrowski z województwa małopolskiego.

Zwraca uwagę niska dynamika wzrostu wartości średnich wskaźnika dla większości analizowanych grup (poza trzema wyżej wymienionymi) pomiędzy latami skrajnymi badanego okresu. Jej zmienność we wszystkich latach okresu ilustruje rycina 8.

Najwyższe były i niemal nieprzerwanie rosły (z wyjątkiem spadku w $2011 \mathrm{r}$. w wyniku weryfikacji REGON-u) średnie powiatów grodzkich metropolitalnych (ryc. 9 i 10). Średnia pozostałych powiatów grodzkich, niewiele niższa niż powiatów metropolitalnych w 2002 r., 
malała do 2007, po czym wykazywała tendencję rosnącą. Tendencję rosnącą wykazywały też będące na dość wysokim poziomie powiaty ziemskie metropolitalne od roku 2006, a na poziomie niższym: powiaty ziemskie miast wojewódzkich od $2005 \mathrm{r}$. i inne ziemskie pośrednie od 2006 r. Pozostałe powiaty ziemskie wykazują stagnację średniego wskaźnika z niewielkimi wahaniami. We wszystkich typach powiatów wystąpił większy wzrost średniej w 2010 r., spadek w 2011 r. (weryfikacja) i prawie równomierny wzrost do końca 2014 r.

W latach 2002-2014 liczba badanych podmiotów wzrosła w 270 powiatach, co stanowi $71 \%$ ich liczby, natomiast wskaźnik na 100 ludności w wieku produkcyjnym wzrósł w 247 powiatach (65\% ich liczby). Różnica wynika ze zmian powyższej liczby ludności. Najwyższą dynamikę zmian wskaźnika miał powiat koniński (143\%), w 6 powiatach grodzkich i 33 ziemskich przekroczyła ona $120 \%$. Dominują wśród nich powiaty metropolitalne (w tym o najwyższej dynamice: powiat wrocławski - dynamika 142,1, piaseczyński - 139,6, warszawski zachodni - 137,3 i lubelski - 134,6), są też powiaty wokół niemetropolitalnych miast wojewódzkich (gorzowski, olsztyński, opolski), turystyczne i, poza wspomnianym konińskim, kilka innych peryferyjnych: grudziądzki, krapkowicki, starogardzki, strzelecki, strzelecko-drezdenecki, włoszczowski, namysłowski i kępiński. W 5 powiatach grodzkich i 26 ziemskich dynamika była poniżej $90 \%$.

Już w tym rozdziale analizuje się dynamikę zmian wskaźników w powiatach grodzkich, ponieważ ich analiza w miastach w następnym rozdziale obejmuje krótszy okres (2009-2014). Najwyższą dynamikę w latach 2002-2014 miały powiaty grodzkie metropolitalne: Warszawa (129), Gdynia (125,1), Sopot (125,1), Piekary Śląskie (124,7), Poznań (124,3). Dużą rozpiętość miała dynamika w powiatach grodzkich Górnośląskiego Obszaru Metropolitalnego, od 102,7 w Mysłowicach po 124,0 w Gliwicach. W Bydgoszczy i Toruniu wskaźniki spadły. Niektóre tylko miasta tej grupy wykazywały wyraźną tendencję wzrostu wskaźnika (z jednym lub dwoma sporadycznymi spadkami). W wielu z nich miał miejsce wyraźny spadek z minimum między rokiem 2005 a 2009.

Bardzo podobnie zmieniały się wskaźniki Olsztyna, Rzeszowa, Białegostoku, Bielsko-Białej, Częstochowy i Legnicy. Różnice dotyczyły poziomu wskaźnika i głębokości spadku do roku 2006 lub 2007, największego w Białymstoku. W większości powiatów grodzkich peryferyjnych wskaźnik spadł, a dynamikę poniżej 90 miały: Przemyśl, Suwałki, Włocławek i Grudziądz.

Tylko w 59 powiatach obie skrajne wartości przypadają na skrajne lata badanego okresu (w 263 maksymalne i tylko w 89 minimalne). Warto zwrócić uwagę na powiaty o największej rozpiętości między wskaźnikiem minimalnym a wskaźnikiem maksymalnym. Rycina 12 przedstawia wskaźniki dla powiatów, w których iloczyn wskaźnika maksymalnego i minimalnego wynosi 1,4 lub więcej. O nierównomierności dynamiki zjawiska świadczą też wzrosty w ostatnim okresie. W latach 2009-2014 badany wskaźnik stanu wzrósł w 317 powiatach (84\% ich liczby), a w latach 2011-2014 - niemal we wszystkich z wyjątkiem 11.

Niektóre spadki liczby podmiotów można przypisać kryzysowi. W roku 2009 spadki wystąpiły w większości powiatów, w 81 przekroczyły 5\% stanu z 2008 r., w 33 - 10\%, a o 1\% spadła liczba firm w całym kraju. Spadki liczby firm w większości powiatów wystąpiły też jednak w roku 2004 i 2011 (weryfikacja), a spadki sumy badanych firm w całym kraju także w roku 2006. W okresie 2008-2010 spadek dotyczył już tylko 108 powiatów, w 47 powyżej 5\%, w 19 - powyżej 19\%. Przyczyną wzrostu liczby spadków były głównie wzrosty liczby wyrejestrowanych firm, w niektórych powiatach bardzo duże. I tak, ponad dwukrotny wzrost był w 2004 r. w 94 powiatach, w 2006 - w 32, w 2009 - w 96, w 2011 - w 40; ponad trzykrotny wzrost zanotowano w 2004 r. w 33 powiatach, a w 2009 r. - w 38. 
Ryc. 8. Liczba osób fizycznych prowadzących działalność gospodarczą na 100 osób w wieku produkcyjnym w latach 2002-1014 - średnie według typów powiatów

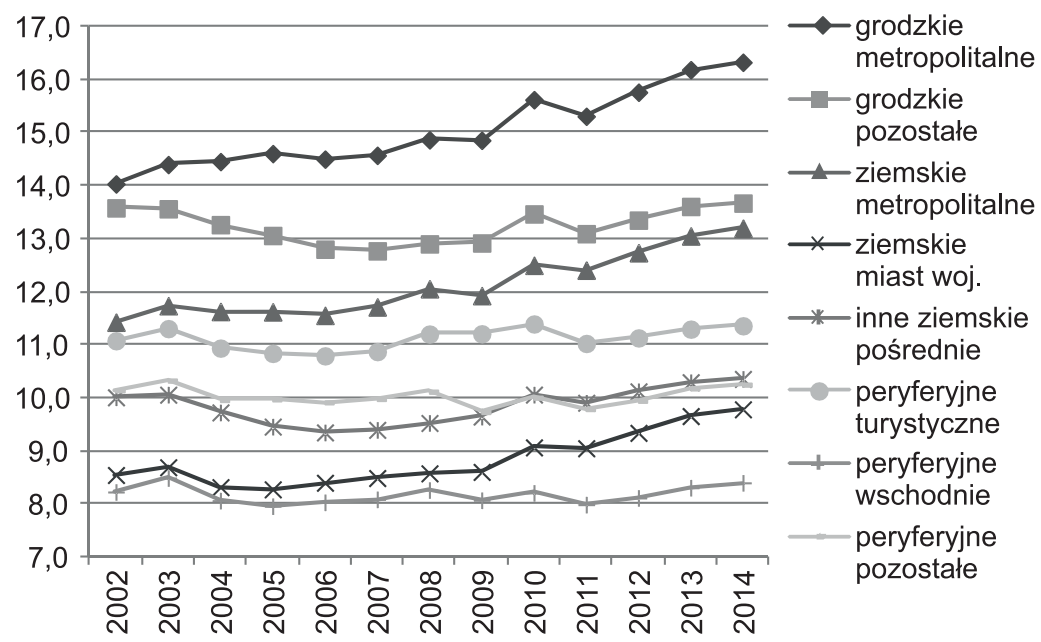

Źródło: opracowanie własne na podstawie danych z Banku Danych Lokalnych GUS

Ryc. 9. Liczba osób fizycznych prowadzących działalność gospodarczą na 100 osób w wieku produkcyjnym w latach 2002-1014 - powiaty ziemskie o najwyższych wskaźnikach stanu

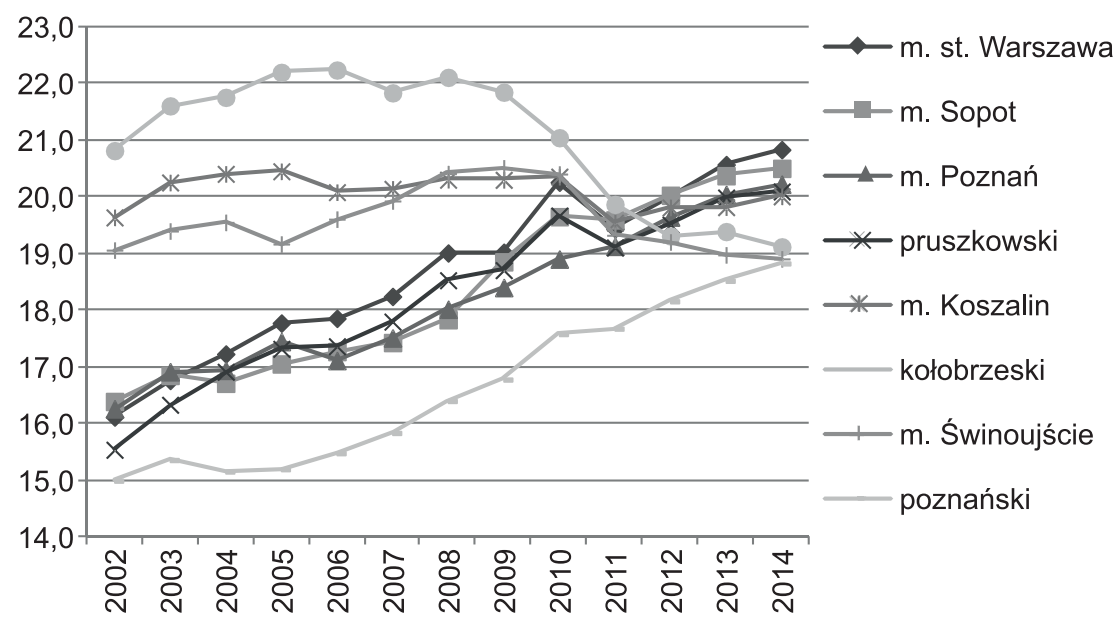

Źródło: opracowanie własne na podstawie danych z Banku Danych Lokalnych GUS 
Ryc. 10. Liczba osób fizycznych prowadzących działalność gospodarczą na 100 osób w wieku produkcyjnym w latach 2002-1014 - powiaty ziemskie o najniższych wskaźnikach stanu

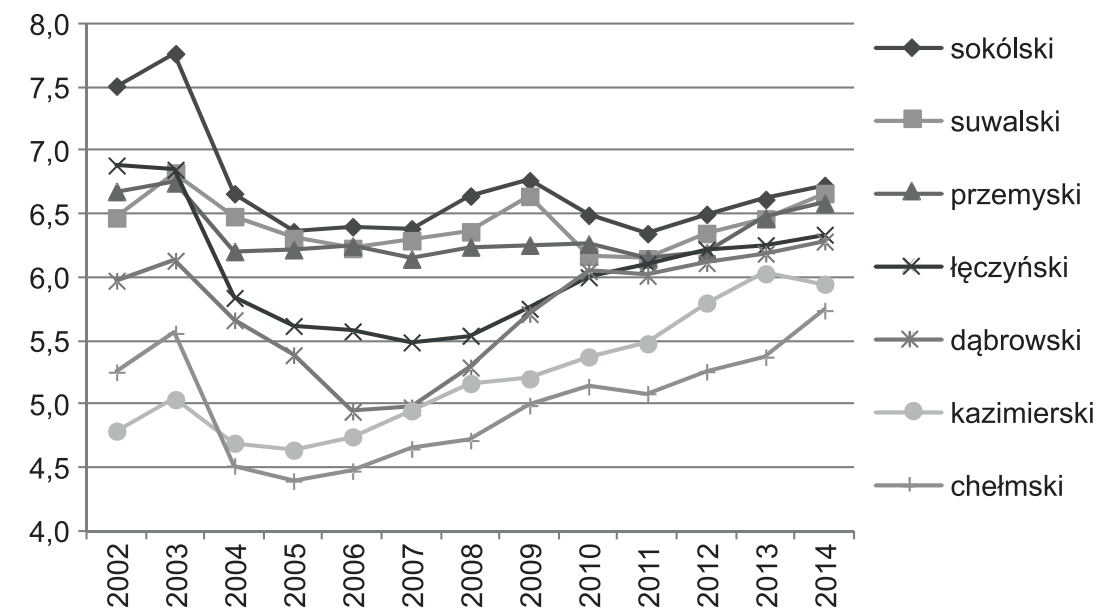

Źródło: opracowanie własne na podstawie Banku Danych Lokalnych GUS

Ryc. 11. Liczba osób fizycznych prowadzących działalność gospodarczą na 100 osób w wieku produkcyjnym wg powiatów - dynamika w latach 2002-2014 (2002 = 100)

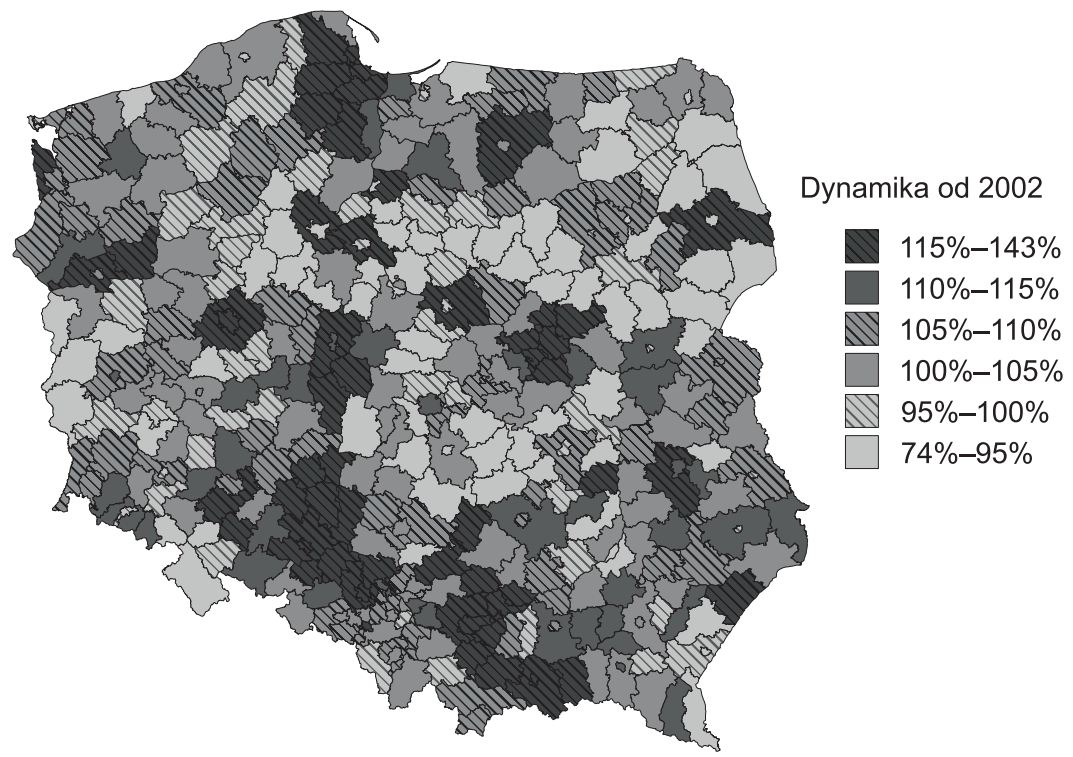

Źródło: opracowanie własne na podstawie danych z Banku Danych Lokalnych GUS 
Ryc. 12. Liczba osób fizycznych prowadzących działalność gospodarczą na 100 osób w wieku produkcyjnym w powiatach grodzkich o największych rozpiętościach wskaźnika

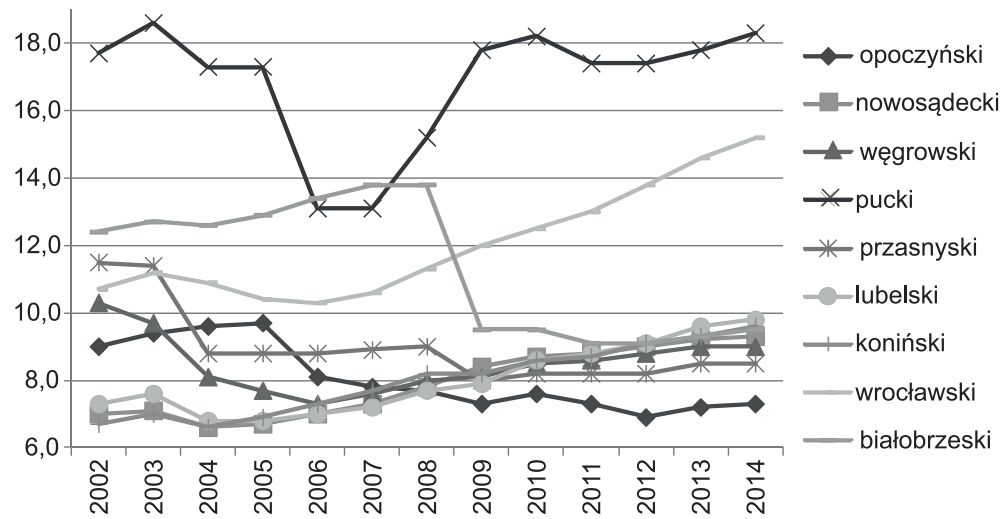

Źródło: opracowanie własne na podstawie danych z Banku Danych Lokalnych GUS

Korelacja dynamiki w latach 2002-2014 i 2009-2014 ze wskaźnikami stanu na początku tych okresów jest bardzo słaba (współczynnik korelacji Pearsona -0,147 i -0,209). Słaba jest też korelacja wskaźnika stanu z udziałem ludności miejskiej w powiatach ziemskich $(0,285$ w 2014 r.). Ujemna korelacja wskaźnika stanu ze stopą bezrobocia stopniowo rosła w latach 2004-2014 od słabej do przeciętnej (od -0,209 do -0,417).

\section{Przedsiębiorcy w gminach}

Jednym z motywów analiz w układzie gmin było zbadanie zjawiska w podziale na miasto i wieś, a w miastach - w zależności od ich wielkości. Dlatego badania prowadzono z wyodrębnieniem miast oraz części wiejskich w gminach miejsko-wiejskich. Badania dynamiki i stanu z 2009 r. nie uwzględniają 17 miast, które prawa miejskie uzyskały po tym roku, a także, w wyniku tego faktu, 17 części wiejskich w gminach miejsko-wiejskich.

Rozkład przestrzenny badanego zjawiska według gmin ilustruje rycina 13. Odczytać z niej można bardziej precyzyjnie prawidłowości analogiczne, jak w układzie powiatów. W niektórych miejscach wyraźnie widoczne są układy pasmowe wzdłuż ciągów transportowych. Można zweryfikować przyczynę wzrostu wskaźnika w karpackich powiatach: gorlickim, jasielskim i krośnieńskim - z turystyką i lecznictwem uzdrowiskowym wiązać można tylko wyższe wskaźniki w gminach Iwonicz i Rymanów. Poza nimi wyższe wskaźniki występują nie w gminach górskich, lecz na linii Gorlice-Krosno.

W badaniach ilościowych wyodrębniono cztery grupy miast: największe (powyżej 300 tys. ludności), inne duże (100-299 tys.), średnie (20-99 tys.) i małe (poniżej 20 tys.). Niektóre wielkości charakteryzujące badane grupy jednostek zawarto w tabeli 3 oraz na rycinie 14 .

Najwyższe maksymalne wskaźniki mają małe miasta turystyczne, w Krynicy Morskiej, Łebie i Jastarni powyżej 40 przedsiębiorców na 1000 ludności w wieku produkcyjnym. Na 30 miast ze wskaźnikiem w 2014 r. powyżej 20 jest 15 miast turystycznych i turystyczno-uzdrowiskowych (głównie małych, z wyjątkiem Zakopanego ze wskaźnikiem 25,6 i Kołobrzegu), 13 miast w obszarach metropolitalnych (9 małych oraz Warszawa, Poznań, Sopot i Józefów; najwyższy wskaźnik ma Podkowa Leśna - 30,3) oraz Koziegłowy (między GOP a Częstochową, 
Ryc. 13. Liczba osób fizycznych prowadzących działalność gospodarczą na 100 osób w wieku produkcyjnym wg gmin w 2009 i 2014 r.

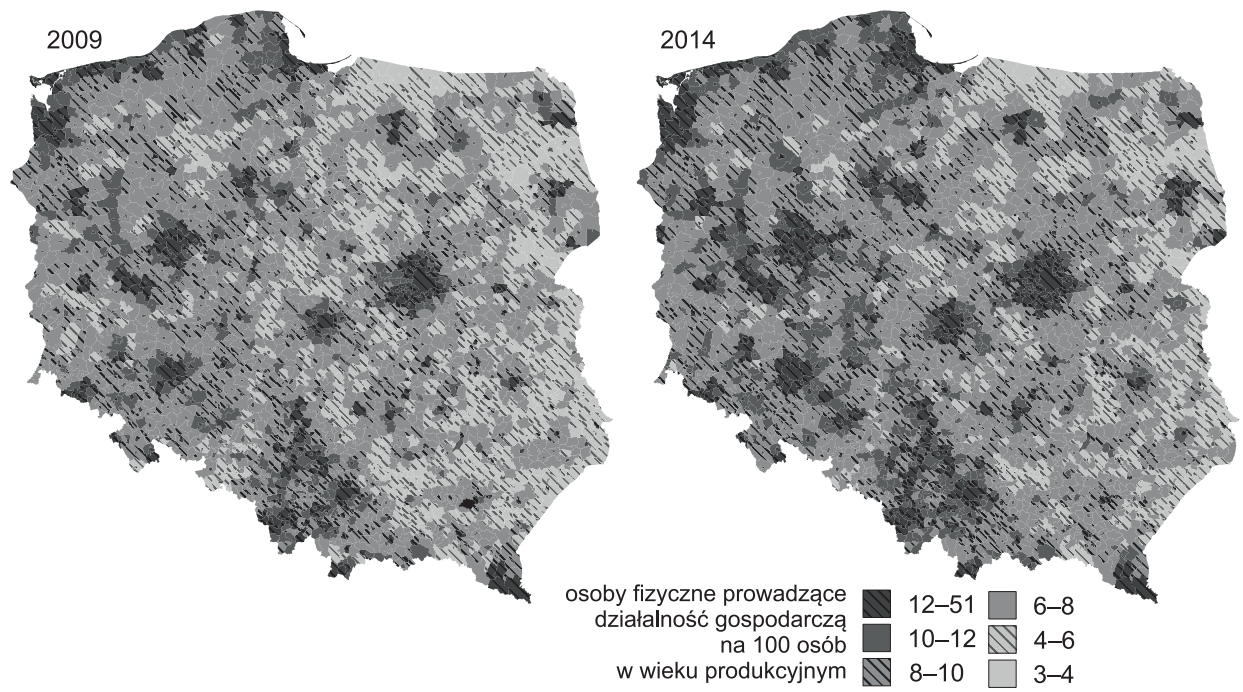

Źródło: opracowanie własne na podstawie danych z Banku Danych Lokalnych GUS

Tab. 3. Liczba osób fizycznych prowadzących działalność gospodarczą na 100 osób w wieku produkcyjnym w latach 2002-2014 - stany i dynamika według grup jednostek

\begin{tabular}{|c|c|c|c|c|c|c|}
\hline & \multirow[b]{2}{*}{ Grupa jednostek } & \multicolumn{4}{|c|}{ W całym okresie 2009-2014 } & \multirow[b]{2}{*}{$\begin{array}{l}\text { Dynamika } \\
2002-2014\end{array}$} \\
\hline & & $\min$. & maks. & średnia & $\begin{array}{c}\text { odchylenie } \\
\text { standardowe } \\
\text { średnie }\end{array}$ & \\
\hline \multirow{4}{*}{ 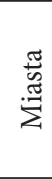 } & powyżej 300 tys. & 12,7 & 20,8 & 16,1 & 2,27 & 109,5 \\
\hline & $100-299$ tys. & 7,9 & 20,4 & 13,0 & 2,55 & 106,6 \\
\hline & 20-99 tys. & 6,4 & 26,6 & 12,9 & 2,98 & 102,3 \\
\hline & poniżej 20 tys. & 4,8 & 48,7 & 12,0 & 4,08 & 102,2 \\
\hline \multicolumn{2}{|c|}{ Gminy wiejskie } & 2,8 & 47,7 & 8,1 & 3,20 & 111,7 \\
\hline \multicolumn{2}{|c|}{$\begin{array}{l}\text { Wieś w gminach miejsko- } \\
\text {-wiejskich }\end{array}$} & 1,1 & 30,2 & 7,9 & 2,66 & 112,9 \\
\hline
\end{tabular}

Źródło: opracowanie własne na podstawie danych z Banku Danych Lokalnych GUS

wskaźnik 26,3) i Koszalin (20,0). Wśród największych miast najniższy wskaźnik miał w 2009 r. Lublin (12,7), a w 2014 r. Bydgoszcz (13,4). Wśród wszystkich miast najniższe wskaźniki miały małe miasta: Krzanowice w 2013 r. (4,8), a w 2014 r. - Pruchnik (5,0). Małe miasta są zatem najbardziej zróżnicowaną grupą miast z punktu widzenia badanego wskaźnika.

Wskaźniki na wsi są ogólnie niższe niż w miastach, o czym świadczą ich średnie (tab. 3). Wynika to $\mathrm{z}$ koncentracji w miastach usług o charakterze funkcji centralnych, a także z niezaliczania do przedsiębiorców rolników. W 19 gminach wiejskich, również i tu głównie turystycznych i metropolitalnych, wskaźnik jest wyższy od 20; przekracza $30 \mathrm{w}$ gminach: Rewal 
Ryc. 14. Liczba osób fizycznych prowadzących działalność gospodarczą na 100 osób w wieku produkcyjnym - wielkości średnie dla grup miast według wielkości (A) i wielkości minimalne i maksymalne dla grup miast według wielkości (B).

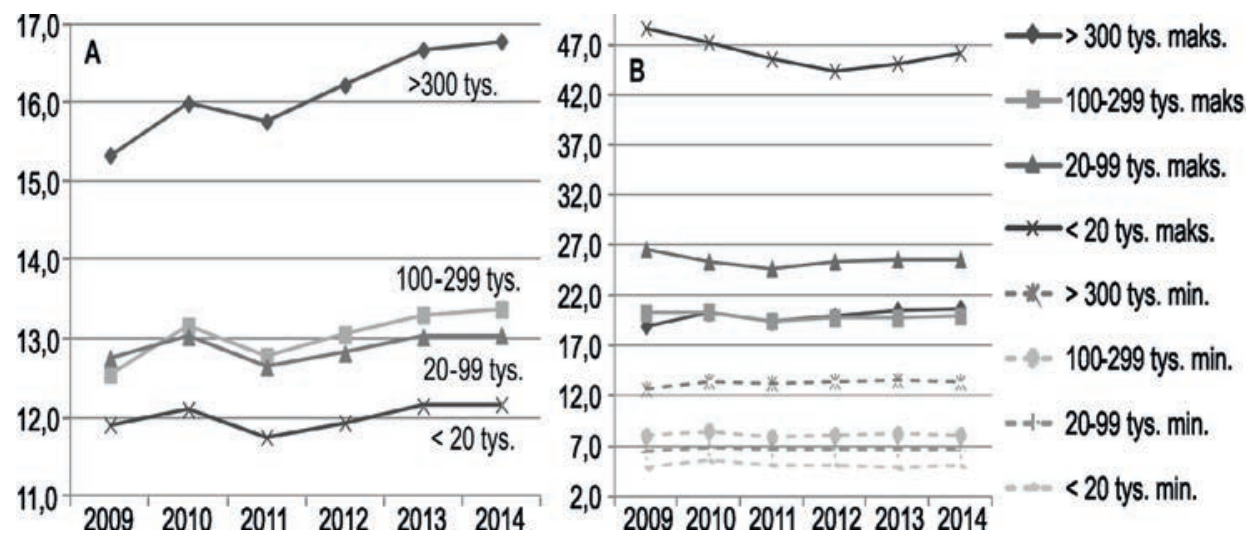

Źródło: opracowanie własne na podstawie danych z Banku Danych Lokalnych GUS

Ryc. 15. Liczba osób fizycznych prowadzących działalność gospodarczą na 100 osób w wieku produkcyjnym wg gmin - dynamika w latach 2009-2014 (2009=100)

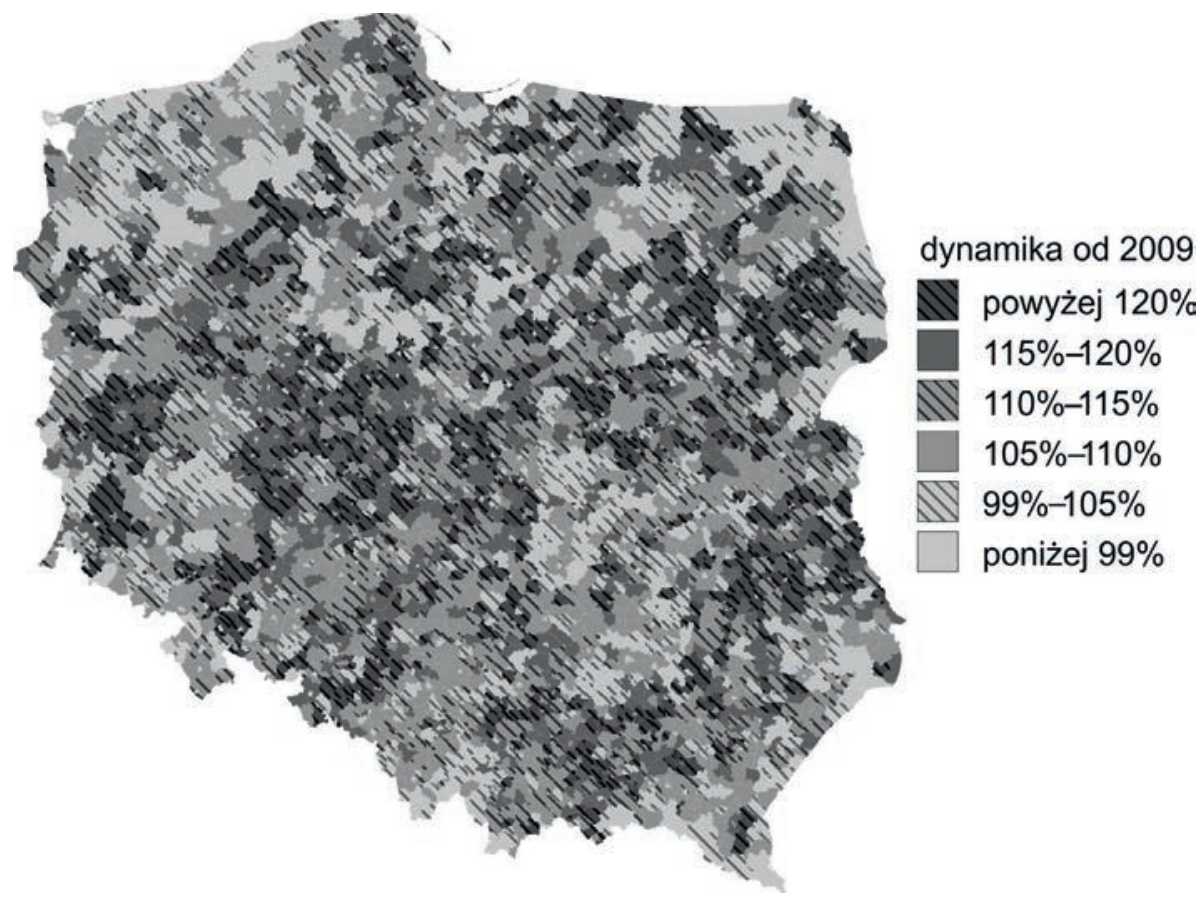

Źródło: opracowanie własne na podstawie danych z Banku Danych Lokalnych GUS 
(46,6), Mielno i Ustronie Morskie, a jeszcze wyższy był w 2009 r. (w Rewalu 50,6). Wskaźniki niższe od 5 ma 5\% liczby gmin wiejskich, najniższe: Nowy Dwór w woj. podlaskim $(2,7)$.

Specyficzną grupą badanych jednostek są części wiejskie gmin miejsko-wiejskich. Wyłączenie z nich miast stanowiących przeważnie największą koncentrację podmiotów gospodarczych powoduje, że w tej grupie jednostek są najniższe wskaźniki, średnia dla ich zbioru niewiele jest jednak niższa niż w gminach wiejskich (tab. 2). Są też i wysokie wskaźniki, zwłaszcza w obszarach metropolitalnych i turystycznych: w 20 gminach wskaźnik przekracza 15, a w 5 - nawet 20. Są to części wiejskie gmin: Dziwnów (wskaźnik 29,5), Międzyzdroje (24,0), Piaseczno (21,6), Łomianki $(21,4)$ i Brwinów $(20,6)$. W 43 gminach wskaźnik nie przekracza 5, niższy od 3 jest w gminach: Korsze, Pruchnik i Czarna Woda.

W grupie największych miast badany wskaźnik w latach 2009-2014 zmalał tylko w Bydgoszczy, w grupie miast o zaludnieniu 100-300 tys. - w Koszalinie i Chorzowie, w miastach średnich - w 29\% ich liczby, a w miastach małych - w 35\% i był to największy udział ze wszystkich 6 badanych grup. W 5 miastach średnich i 40 małych dynamika była poniżej 90. Malały m.in. wskaźniki najwyższe w miastach i gminach turystycznych, co może świadczyć o nasyceniu badanymi podmiotami. Najwyższe średnie dynamiki wzrostu miały obie grupy jednostek wiejskich: gminy wiejskie i części wiejskie gmin miejsko-wiejskich (tab. 3, ryc. 15). Wskaźnik zmalał tylko w $12 \%$ liczby gmin wiejskich (w 2,2\% dynamika była niższa od 90) i w 9\% gmin miejsko-wiejskich w ich częściach wiejskich (w 2,5\% dynamika niższa od 90). Do wszystkich spadków przyczyniła się weryfikacja w $2011 \mathrm{r}$.

Bardzo słabe są korelacje dynamiki ze wskaźnikiem z roku 2009 (-0,210 dla miast, 182 dla gmin wiejskich, $-0,160$ dla części wiejskich gmin miejsko-wiejskich), a także wskaźnika stanu z liczbą ludności miast (0,106 w 2009 r., 0,145 w 2014 r.). Wskaźnik stanu wykazuje dość wysoką korelację z dochodami własnymi gmin miejskich (0,552 w 2009 r., 0,612 w 2014 r.) i znacznie niższą dla gmin wiejskich (0,367 w 2009 r., 0,274 w 2010 r., 0,299 w 2014 r.).

\section{Podsumowanie i wnioski}

Badania wykazały duże zróżnicowanie badanego zjawiska w czasie i jeszcze większe w przestrzeni oraz następujące prawidłowości: najwyższe wskaźniki stanu są na obszarach turystycznych i metropolitalnych (na poziomie gmin - w małych miastach i gminach wiejskich na tych obszarach), wskaźniki maleją z zachodu na wschód Polski, wskaźniki w miastach są generalnie wyższe niż na wsi. Bardzo słaba jest korelacja wskaźników z wielkością miast oraz wskaźników stanu z dynamiką, wyraźna jest korelacja wskaźników stanu z dochodami własnymi gmin i bardzo wysoka jest korelacja z PKB w układzie podregionów. Ta ostatnia świadczy o tym, iż przedsiębiorczość przejawiająca się w tworzeniu i liczbie firm w większym stopniu niż czynnikiem jest efektem rozwoju wywołanym przez inne czynniki. Jest to zrozumiałe, zważywszy na fakt, iż wśród badanych firm dominują podmioty mikro, w przeważającej mierze jednoosobowe i działające w sektorze endogenicznym, a żywotność wielu nie jest długa.

Analizy nie pozwoliły stwierdzić, czy i gdzie nastąpił stan nasycenia. Jest on najbardziej prawdopodobny w niektórych gminach turystycznych, zwłaszcza nadmorskich, o bardzo wysokich i malejących wskaźnikach. Stan taki istnieje zapewne na każdym terytorium, warunkowany przez układ barier. Istnienie barier i wniosek kończący poprzedni akapit potwierdzają przypuszczenie, że w politykach rozwoju nadmiernie akcentuje się tworzenie nowych firm, za mało - wspieranie rozwoju firm istniejących. Rozwój polega nie tyle na tworzeniu nowych 
firm, ile na ich wzroście, zatrudnianiu pracowników, przekształcaniu firm mikro w małe, a małych - w średnie. O rozwoju decyduje bowiem nie liczba firm, lecz ich potencjał i zdolność wypromowania konkurencyjnych produktów.

Uzasadnione są dalsze badania zjawiska, w tym: opierające się na danych statystycznych (korelacje z liczbą rolników, struktura podmiotów według sektorów i sekcji PKD, sprawdzenie, jak kształtują się wielkości bez sekcji I (zakwaterowanie, gastronomia), a także socjologiczne - ankietowe - badające przyczyny zjawiska i uwarunkowania na przyszłość (poziom nasycenia, bariery).

\section{Literatura}

References

Bank Danych Lokalnych. GUS (2015, 10 września). Pozyskano z: www.stat.gov.pl.

Dorocki, S., Brzegowy, P. (2012). Regionalne zróżnicowanie kształcenia we Francji w aspekcie rozwoju przedsiębiorczości departamentów zamorskich. Przedsiębiorczość - Edukacja, 8, 229-258.

Dorocki, S., Brzegowy, P. (2014). Uwarunkowania przestrzennego zróżnicowania postaw przedsiębiorczych we Francji. Przedsiębiorczość - Edukacja, 10, 149-163.

Iwańska, M., Bieńkowska, W. (2010). Zróżnicowanie wartości wskaźnika przedsiębiorczości w gminach wiejskich województwa mazowieckiego w układzie przestrzennym. Acta Sci. Polonorum Oeconomia, 9(3), 119-127.

Koncepcja przestrzennego zagospodarowana kraju 2030 (2011). Ministerstwo Rozwoju Regionalnego, Warszawa.

Krakowiak-Bal, A. (2007). Wpływ infrastruktury na rozwój przedsiębiorczości w gminach wiejskich wybranych powiatów woj. małopolskiego. Inżynieria Rolnicza, 11, 101-108.

Kudłacz, T., Reśko, D. (2007). Przedsiębiorczość w subregionie nowosądeckim w latach 2001-2004. Zeszyty Naukowe/Akademia Ekonomiczna w Krakowie, 746, 51-66.

Kurek, S. (2010). Przestrzenne zróżnicowanie poziomu rozwoju regionalnego w Unii Europejskiej w świetle wybranych mierników. Prace Komisji Geografii Przemysłu Polskiego Towarzystwa Geograficznego, 16, 87-104.

Makieła, Z. (2007). Przedsiębiorczość w Polsce w układzie regionalnym. Przedsiębiorczość - Edukacja, $3,18-23$.

Młodak, A. (2012). Statystyka metropolii polskich - problemy i perspektywy. Studia Regionalne i Lokalne, 2(48), 20-38.

Płaziak, M., Rachwał, T. (2015). „Przedsiębiorczy region” - zarys koncepcji w świetle analizy roli przedsiębiorczości w krajowej strategii rozwoju regionalnego. Przedsiębiorczość - Edukacja, 11, 37-49.

Rachwał T., Boguś. M. (2012). Konkurencyjność przedsiębiorstw przemysłowych w Polsce w ujęciu regionalnym na tle innych krajów Unii Europejskiej. W: P. Raźniak (red.) Przekształcenia struktur regionalnych, Kraków: Krakowskie Towarzystwo Edukacyjne - Oficyna Wydawnicza AFM: na zlecenie Krakowskiej Akademii im. Andrzeja Frycza Modrzewskiego, 9-36.

Raport o stanie o stanie sektora matych $i$ średnich przedsiębiorstw $w$ Polsce $w$ latach 2011-2013. PARP (2015, 10 września). Pozyskano z: http://www.parp.gov.pl/files/74/81/626/18355.pdf.

Rozwój Polski Wschodniej (2015, 10 września). Pozyskano z: http://www.porpw.com.pl/.

Salamon, J. (2009). Przestrzenne zróżnicowanie wartości wskaźnika przedsiębiorczości na obszarach wiejskich województwa świętokrzyskiego. Infrastruktura i Ekologia Terenów Wiejskich, 5, 231-239.

Strojny, J., Kościółek M. (2015). Przedsiębiorczość Polski Wschodniej - ocena potencjału rozwojowego z wykorzystaniem analizy porównawczej. Przedsiębiorczość - Edukacja, 11, 64-81.

Strojny, J. (2010). Analiza potencjału przedsiębiorczego województwa podkarpackiego. Przedsiębiorczość Edukacja, 6, 176-197. 
Jacek Sołtys, dr hab. inż., Politechnika Gdańska, Wydział Architektury, Katedra Urbanistyki i Planowania Regionalnego. Absolwent Wydziału Architektury Politechniki Gdańskiej. Prowadzone zajęcia dydaktyczne: planowanie regionalne (w latach 1975-2014), lokalne planowanie przestrzenne, planowanie strategiczne, projektowanie zagospodarowania rekreacyjnego i turystycznego. Zainteresowania naukowe: metody planowania (przestrzennego i strategicznego, w tym metoda scenariuszy), rozwój zrównoważony, typologia miast i regionów, sieć osadnicza, aktywizacja gospodarcza obszarów peryferyjnych. Pracował w wielu krajowych i międzynarodowych projektach badawczych. Autor 2 książek i ponad 40 innych publikacji. Współautor ponad 30 strategii dla gmin. Członek Europejskiego Stowarzyszenia Nauk Regionalnych (ERSA) i Towarzystwa Urbanistów Polskich. Przewodnik turystyczny.

Jacek Soltys, Graduated from Gdansk University of Technology, Faculty of Architecture. Teaching duties (courses taught): regional planning (since 1975-2014), local planning, strategic planning, designing of tourist and recreational areas development. Research interests: methods of planning (spatial, strategic, including scenario method), sustainable development, typology of towns and regions, settlement network, regional development of peripheral areas. He has worked in numerous international and national research projects. Author of two books and more than 40 other publications. Co-author of more than 30 strategies for municipalities. Member of the European Regional Science Assotiation and Society of Polish Town Planners. Tourist guide.

\author{
Adres/Address: \\ Politechnika Gdańska \\ Wydział Architektury \\ Katedra Urbanistyki i Planowania Regionalnego \\ ul. Gabriela Narutowicza 11/12 \\ 80-233 Gdańsk, Polska \\ e-mail: jacek.soltys@gmail.com
}

Sławomir Dorocki, dr, Uniwersytet Pedagogiczny im. Komisji Edukacji Narodowej w Krakowie, Instytut Geografii, Zakład Przedsiębiorczości i Gospodarki Przestrzennej. Absolwent studiów z zakresu geografii społeczno-ekonomicznej Uniwersytetu Pedagogicznego w Krakowie, doktor nauk humanistycznych w dyscyplinie historia (Instytut Europeistyki - Uniwersytet Jagielloński). Adiunkt w Instytucie Geografii Uniwersytetu Pedagogicznego w Krakowie. Zainteresowania badawcze autora skupiają się wokół problematyki regionów i procesów regionalizacji społeczno-gospodarczej, ze szczególnym uwzględnieniem zróżnicowania przestrzeni europejskiej oraz procesów integracji europejskiej i uwarunkowań historycznych.

Sławomir Dorocki, PhD, Pedagogical University of Cracow, Institute of Geography, Department of Entrepreneurship and Spatial Management. Graduated from the Pedagogical University in Cracow with MS degree in geography, $\mathrm{PhD}$ in history (Institute of European Studies of the Jagiellonian University). Assoc. professor at the Pedagogical University of Cracow, Institute of Geography. His research interests are tied with regional problems and processes of socio-economic regionalization, with particular emphasis on the diversity of Europe, processes of European integration and historical conditions.

\title{
Adres/Address:
}

Uniwersytet Pedagogiczny im. Komisji Edukacji Narodowej w Krakowie

Instytut Geografii

Zakład Przedsiębiorczości i Gospodarki Przestrzennej

ul. Podchorążych 2

30-084 Kraków, Polska

e-mail: sdorocki@up.krakow.pl 